\title{
Assessing Information System Success in E-Learning
}

\author{
Syaiful Bakhri \\ Universitas Islam Negeri Walisongo Semarang, Indonesia \\ \{syaifulbakhri@walisongo.ac.id\}
}

\begin{abstract}
E-Learning as an information system for distance learning that can provide convenience in the process of teaching and learning activities both from the teacher and student side, the e-learning system has the characteristics of high flexibility that is not limited by place and time, independent learning where students can play an active role in the learning process, and save costs in terms of administration, facilities, transportation, and accommodation. Currently, UIN Walisongo has used the eLearning by all lecturers and students for teaching and learning, needs to be done after the implementation of e-learning is to test the success of e-learning. This study aims to test the success of e-Learning in the learning process at UIN Walisongo. The factors used in this test are information quality, system quality, service quality, user satisfaction, and net benefit. These factors are thought to have an impact on the success of the e-learning system at UIN Walisongo. The Testing of information systems in e-learning uses the model DeLone and McLean with the Structural Equation Modeling (SEM) method and SMART-PLS tools. This study results should be considered so that it is expected to increase the e-learning system in the future.
\end{abstract}

Keywords: Structural Equation Modeling (SEM); E-Learning; DeLone and McLean

\section{Introduction}

E-Learning is a term that is usually used in teaching and learning activities and in its implementation using information and communication technology. In addition, the term Elearning is also used as a mode of teaching and learning activities such: Online learning, Virtual learning, Distributed learning, Network and web-based learning [1]

Through the use of technology and communication, of course, E-learning can reach distance learning. While G. Chopra, P. Madan, P. Jaisingh, and P. Bhaskar [2] emphasized the notion of e-learning in their method, namely E-learning is a term for technology-based learning that involves learning methodologies via the internet or intranet, video conferences, and satellite broadcast. Related to this understanding, the use of E-learning in teaching and learning activities in the field of education is very important, because besides being able to be done online and have a wider reach, E-learning can also make it easier for both teachers and students to be more interactive.

UIN Walisongo Semarang has implemented E-learning and is used by students and lecturers in the process of teaching and learning activities. However, the use of E-learning is still not optimal because there are still obstacles in accessing E-Learning, which result in the 
absorption of material by students/learners being less than optimal. Therefore this research was conducted to analyze the factors that influence the success of E-learning at UIN Walisongo.

The successful implementation of E-learning at UIN Walisongo is felt to be very important to welcome the era of the fourth generation revolution (Industrial Revolution 4.0), which is marked by increased connectivity, interaction, artificial intelligence, and virtual reality. One of the models developed to evaluate the success of information systems is to use the DeLone and McLean model [3], in which the model evaluates the factors of information quality, system quality, service quality, intention to use, use, user satisfaction, and net benefits.

\section{Metode Penelitian}

This research uses the purposive sampling method. Where is purposive sampling selected through the determination of certain criteria by specific researchers/groups. The information system model used in this study to evaluate the implementation of e-learning at UIN Walisongo and to analyze the factors that can influence the success of e-learning is the DeLone and McLean models. The results of the evaluation and analysis of these factors can be used as recommendations for improving the implementation of the e-learning information system at UIN Walisongo.

The data will be analyzed using the variance-based SEM method (PLS), the number of samples used can range from 30 - 100 [5]. The measurement scale in this research questionnaire uses a Likert scale model. The Likert scale used is a Likert scale with five categories, ranging from 1 to strongly disagree (STS), 2 to disagree (TS), 3 to doubt (R), 4 to agree $(\mathrm{S})$, and 5 to agree. Strongly agree (SS).

\subsection{Analisis Data}

\section{a) Descriptive Analysis}

Descriptive analysis was carried out on the demographic side of respondents, or users obtained through interviews and questionnaires in terms of gender, E-learning used, and supporting media for E-learning for video conferencing.

\section{b) Quantitative Analysis}

The quantitative analysis used in this study uses Structural Equation Modeling (SEM) analysis. SEM analysis was conducted to determine the relationship between factors. As has been explained in the research method, this study uses the basis of DeLone and McLean's information system model. The DeLone and McLean models can be seen in Figure 1. However, in this study, several modifications were made to the DeLone and McLean models used, namely eliminating the intention of use and use factors. This is done to adjust the conditions of e-learning at UIN Walisongo that have been implemented.

Therefore, this research is only seen from the point of view of customer satisfaction (user satisfaction) and does not analyze the net benefits back. The DeLone and McLean information system models that have been modified in this study can be seen in Figure 2. While the factors and indicators to be analyzed in this study can be seen in Table 2. 


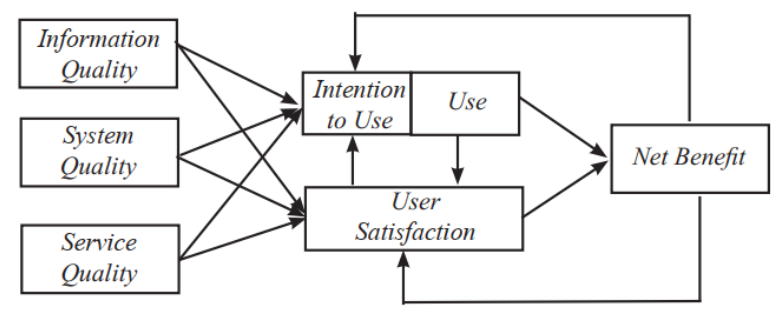

Fig. 1. The Update Delone and McLean

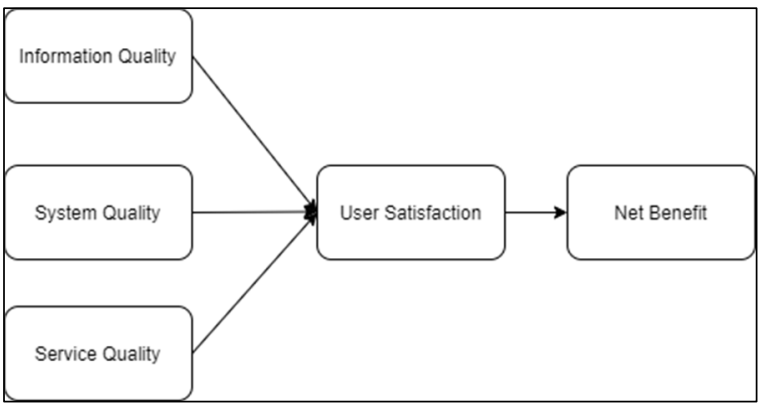

Fig.2. The Proposes Research Model

\subsection{Hypothesis}

Information quality is a measure of the quality that comes from an information system. System quality is a measure of the success of a system, whether seen from the procedures, devices used, and the rules contained therein and informed according to user needs. Meanwhile, service quality is an achievement of customer service that can be measured by comparing customer expectations with the reality of the services provided. User statistics are customer responses to the satisfaction of an information system, and net benefit is an advantage that customers feel from using an information system. Based on the relationship between the above factors, this study can formulate a hypothesis, which can be seen in table 1 .

Table 1. Factors in Research

\begin{tabular}{clc}
\hline No. & \multicolumn{1}{c}{ Hypothesis } & \multicolumn{1}{c}{ References } \\
\hline 1. & $\begin{array}{l}\text { Service quality has an effect } \\
\text { on user satisfaction }\end{array}$ & {$[5][6][7][8][9]$} \\
2. & $\begin{array}{l}\text { Information quality affects } \\
\text { user satisfaction }\end{array}$ & {$[5][6][10][8]$} \\
3. & $\begin{array}{l}\text { System quality affects user } \\
\text { satisfaction }\end{array}$ & {$[5][6][7][8]$} \\
4 & $\begin{array}{l}\text { User Satisfaction affects in } \\
\text { Net Benefit }\end{array}$ & {$[10][8]$} \\
\hline
\end{tabular}

Table 2. Indicators in Research

\begin{tabular}{lclc}
\hline \multicolumn{1}{c}{ Factors } & Symbol & \multicolumn{1}{c}{ Indikator } & Adapted From \\
\hline Informati & IQ1 & Accessibility & {$[11]$} \\
on & IQ2 & Useful & {$[12][11]$} \\
Quality & IQ3 & Up to date & {$[12][11]$} \\
\hline
\end{tabular}




\begin{tabular}{lclc}
\hline \multicolumn{1}{c}{ Factors } & Symbol & \multicolumn{1}{c}{ Indikator } & Adapted From \\
\hline System & SQ1 & Easy to Use & {$[12][11]$} \\
Quality & SQ2 & User Friendly & {$[11]$} \\
Service & SQ1 & Available & {$[12][11]$} \\
Quality & SQ2 & $\begin{array}{l}\text { Fair } \\
\text { Understanding }\end{array}$ & {$[12][11]$} \\
User & US1 & $\begin{array}{l}\text { Overall } \\
\text { Satisfaction }\end{array}$ & {$[12]$} \\
Satisfacti & & $\begin{array}{l}\text { Enjoyable } \\
\text { Experience }\end{array}$ & {$[12]$} \\
on & US2 & $\begin{array}{l}\text { Benefit to } \\
\text { Studies }\end{array}$ \\
Net & NB1 & {$[12]$} \\
Benefit & & Cost Saving & {$[3]$} \\
& NB2 & Time Saving & {$[3]$} \\
\hline
\end{tabular}

\section{Results and Discussion}

Data from the demographics of respondents from this study generated from questionnaires to users as respondents can be seen in table 3 .

Table 3. Respondents Demography

\begin{tabular}{llc}
\hline No. & Respondents Identity & Amount \\
\hline 1. Gender & \\
a. Man & 20 \\
b. Woman & 80 \\
2. E-Learning Used & \\
a. E-learning UIN Walisongo & 97 \\
b. Google Classroom & 3 \\
3. E-learning support media & 58 \\
a. Zoom & 23 \\
b. Google Meet & 17 \\
c. WhatsApp & 2 \\
d. VCon UIN Walisongo &
\end{tabular}

In table 3., it can be seen that the number of women is more, namely by 80 people, while the number of men is 20 people. Most of the respondents used UIN Walisongo's E-learning as a platform used for the learning process compared to Google Classroom, while the supporting media for video conferencing in order of respondents chose to use zoom, google meet, followed by WhatsApp, and finally video conference (VCON) UIN Walisongo. If you look at the respondent's data above, the teaching and learning activities at UIN Walisongo are very interactive and complementary between the E-learning platform and video conference tools.

The application of e-Learning at UIN Walisongo can be seen from the results of the questionnaire given. In terms of information quality, system quality, service quality, user satisfaction, and net benefits, respondents overall stated that they were quite good (mean>3), which can be seen in the Table. Although, in general, the average is quite good, the user satisfaction variable is lower among other variables. This is necessary to improve the Elearning system where overall user satisfaction in using the system and user experience in using the E-Learning system. 
Table 4. Value Mean from Construct

\begin{tabular}{|c|c|c|c|}
\hline Construct & Item & Factors & Mean \\
\hline Information & IQ1 & Accessibility & 3.86 \\
\hline Quality & IQ2 & Useful & 3.81 \\
\hline & IQ3 & Up to date & 3.95 \\
\hline System & SQ1 & User Friendly & 3.61 \\
\hline Quality & SQ2 & Easy to Use & 3.68 \\
\hline Services & ScQ1 & Available & 3.15 \\
\hline Quality & ScQ2 & $\begin{array}{l}\text { Fair } \\
\text { Understanding }\end{array}$ & 3.44 \\
\hline User & US1 & Overall & 3.45 \\
\hline Satisfaction & US2 & $\begin{array}{l}\text { Satisfaction } \\
\text { Enjoyable } \\
\text { Experience }\end{array}$ & 3.35 \\
\hline Net Benefit & $\begin{array}{l}\text { NB1 } \\
\text { NB2 } \\
\text { NB3 }\end{array}$ & $\begin{array}{l}\text { Benefit to studies } \\
\text { Cost Saving } \\
\text { Time Saving }\end{array}$ & $\begin{array}{l}3.51 \\
3.54 \\
3.65\end{array}$ \\
\hline
\end{tabular}

SEM-PLS analysis by running the PLS Algorithm to carry out the testing process. Results According to Hair et al. [13] testing the validity, there are three parameters that need to be tested, namely the factor loading value for all indicators has a minimum value of 0.6 . the composite reliability has a minimum value of 0.7 and a minimum AVE value of 0.5 . When viewed from the aspect of the factor loading, Time-saving has a lower value in contributing to the net benefit, and then overall factor loading has met the requirements, namely $>0.6$ can be selected in Table 4 and Figure 4. Testing of other parameters is by looking at the value. Composite reliability in the range 0.863 to 0.958 , which means that the value in that range is in accordance with the required value, which is more than 0.6 . The next test is to look at the AVE value, where the value for all factors is more than 0.5 .

The next stage is to measure the structural model, namely the relationship between construct variables. At this stage, what is seen is the reliability of Cronbach. This analysis is conducted to determine the consistency of the instrument in measuring a concept with a value of more than 0.6. In table 4, it can be seen that the Cronbach's Alpha value is more than 0.6, which is a reliable model measurement.

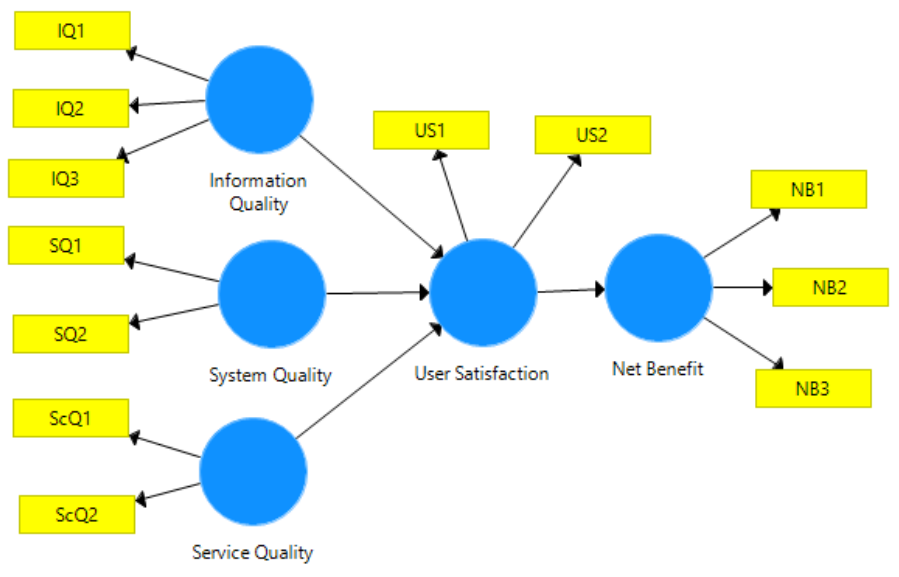

Fig. 3. Relationship Factors 
Table 5. Convergent Validity Test Results

\begin{tabular}{lccccc}
\hline \multicolumn{1}{c}{ Factors } & Symbol & $\begin{array}{c}\text { Factor } \\
\text { Loading }\end{array}$ & $\begin{array}{c}\text { Composite } \\
\text { Reliability }\end{array}$ & $\begin{array}{c}\text { Cronbach's } \\
\text { Alpha }\end{array}$ & \multirow{2}{*}{ AVE } \\
\hline Information Quality & IQ1 & 0.903 & 0.932 & 0.891 & 0.821 \\
& IQ2 & 0.914 & & & \\
System Quality & IQ3 & 0.900 & & & \\
& SQ1 & 0.949 & 0.941 & 0.876 & 0.889 \\
Services Quality & SQ2 & 0.937 & & & \\
& ScQ1 & 0.846 & 0.863 & 0.685 & 0.759 \\
User Satisfaction & ScQ2 & 0.896 & & & \\
\multirow{2}{*}{ Net Benefit } & US1 & 0.958 & 0.958 & 0.913 & 0.920 \\
& US2 & 0.960 & & & \\
& NB1 & 0.918 & 0.890 & 0.815 & 0.731 \\
& NB2 & 0.879 & & & \\
\hline
\end{tabular}

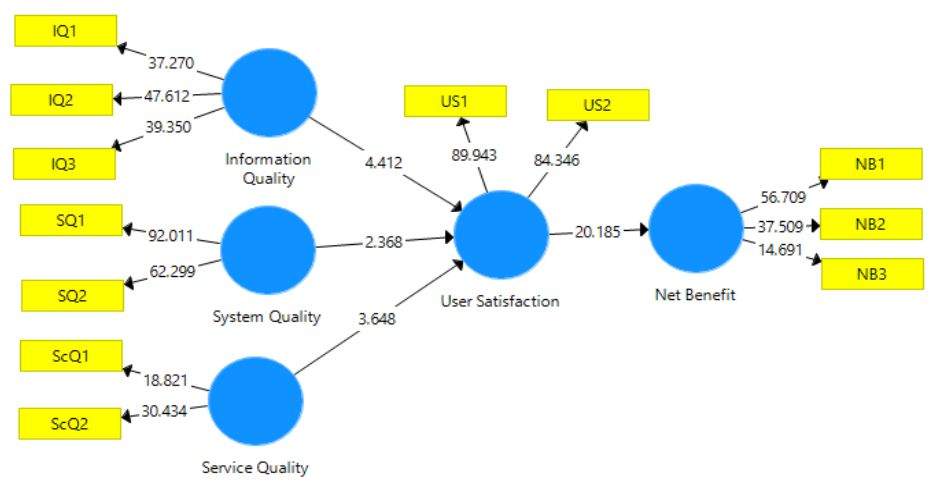

Fig. 4. Structural Model Results

In testing the hypothesis, it is necessary to run bootstrapping on PLS-SEM in order to know the T-Statistic and P-Value values, where the hypothesis is accepted if t-statistics $>\mathrm{t}$ table (1.96) and $\mathrm{P}$ values $<0.05$. In table 5 ., the results of bootstrapping show that information quality, system quality, and service quality have a significant effect on user satisfaction. And user satisfaction has a significant effect on net benefits.

Table 6. Hypothesis Test

\begin{tabular}{|c|c|c|}
\hline Hypothesis & T-Statistics & P Values \\
\hline $\begin{array}{l}\text { Information } \\
\text { quality affects } \\
\text { user }\end{array}$ & 4.412 & 0.000 \\
\hline $\begin{array}{l}\text { satisfaction } \\
\text { Service quality } \\
\text { has an effect on } \\
\text { user } \\
\text { satisfaction }\end{array}$ & 3.648 & 0.000 \\
\hline $\begin{array}{l}\text { System quality } \\
\text { affects user } \\
\text { satisfaction }\end{array}$ & 2.368 & 0.018 \\
\hline
\end{tabular}




\begin{tabular}{lcc}
\hline \multicolumn{1}{c}{ Hypothesis } & T-Statistics & P Values \\
\hline User & 20.185 & 0.000 \\
Satisfaction & & \\
affects net & & \\
benefit & & \\
\hline
\end{tabular}

\section{Managerial Implications}

Based on the results of the research that has been done, the suggestion from the author to the e-learning manager of UIN Walisongo is to maintain and try to improve the e-learning system that is already good. Improvements can be made from all sides, from information systems, system quality, and service quality. Efforts to improve the information system can be made according to priority sequentially, starting from useful then accessibility and followed by up to date. The increase in system quality is done from user friendly and easy to use. Meanwhile, in service quality, the first increase to be made is available, after which an increase in fair understanding. Based on the use of statistics, the e-learning system improvements in a sequence are Enjoyable Experience and Overall Satisfaction. Efforts to increase the net benefit from the implementation of the e-learning system at UIN Walisongo can be carried out starting from benefits to studies because studies are the main users of elearning, then an increase in cost-saving and then time-saving.

\section{Conclusions and Suggestions}

The conclusion of this research is that the overall implementation of e-learning at UIN Walisongo has been good. This can be seen in terms of information systems, system quality, service quality, user statistics, and net benefits, all of which produce values (mean $>3$ ).

The factors that can influence the user statistics of e-learning at UIN Walisongo are information system, system quality, service quality, and the influence of these three factors also have an impact on the net benefits that are formed from indicators of benefits to studies, cost-saving and time-saving. This can be proven from the results of the hypothesis that all factors have a $\mathrm{p}$-value $<0.05$ and $\mathrm{T}$ statistic $>\mathrm{T}$ table (1.96).

Indirectly, the influence of each factor sequentially is the effect of user statistics on net benefits, the influence of information systems on user statistics, the effect of service quality on user statistics, and the effect of system quality on user statistics.

\section{Suggestion}

The suggestion from this research is that further research can be carried out more broadly, not only at UIN Walisongo but also at several tertiary institutions that use e-learning. In addition, research can also be carried out using other models besides DeLone and McLean with or without modification. As well as for further research, can analyze the return value of the net benefit because this is very interesting to study.

\section{References}

[1] A. P. Chitra and M. A. Raj, "E-Learning," vol. 3, pp. 11-13, 2018. 
[2] G. Chopra, P. Madan, P. Jaisingh, and P. Bhaskar, "Effectiveness of e-learning portal from students' perspective: A structural equation model (SEM) approach," Interact. Technol. Smart Educ., vol. 16, no. 2, pp. 94-116, 2019, doi: 10.1108/ITSE-05-20180027.

[3] W. H. DeLone and E. R. McLean, "The DeLone and McLean model of information systems success: A ten-year update,” J. Manag. Inf. Syst., vol. 19, no. 4, pp. 9-30, 2003, doi: 10.1080/07421222.2003.11045748.

[4] A. S. Hussein, "Penelitian Bisnis dan Manajemen Menggunakan Partial Least Squares dengan SmartPLS 3.0," Univ. Brawijaya, vol. 1, pp. 1-19, 2015, doi: 10.1023/A:1023202519395.

[5] G. A. A. Wisudiawan, "Analisis faktor kesuksesan sistem informasi menggunakan model delone and mclean,” J. Ilm. Teknol. Inf. Terap., vol. 2, no. 1, pp. 55-59, 2015.

[6] S. Ozkan and R. Koseler, "Multi-dimensional students' evaluation of e-learning systems in the higher education context: An empirical investigation," Comput. Educ., vol. 53, no. 4, pp. 1285-1296, 2009, doi: 10.1016/j.compedu.2009.06.011.

[7] D. R. Rammer and S. L. Zelinka, "Optical method for measuring the surface area of a threaded fastener," Exp. Tech., vol. 34, no. 4, pp. 36-39, 2010, doi: 10.1111/j.17471567.2009.00538.x.

[8] A. Rahmat, K. B. Seminar, and A. I. Suroso, "Evaluasi Keberhasilan E-Learning Dalam Perspektif Sistem Informasi (Studi Kasus Universitas Terbuka)," J. Apl. Bisnis dan Manaj., vol. 5, no. 3, pp. 373-384, 2019, doi: 10.17358/jabm.5.3.373.

[9] H. B. Seta, T. Wati, A. Muliawati, and A. N. Hidayanto, "E-learning success model: An extention of delone \& mclean is' success model," Indones. J. Electr. Eng. Informatics, vol. 6, no. 3, p. 281 291, 2018, doi: 10.11591/ijeei.v6i3.505.

[10] N. Seliana, A. I. Suroso, and L. N. Yuliati, "Evaluation of E-Learning Implementation in the University Using Delone and Mclean Success Model," J. Apl. Manaj., vol. 18, no. 2, pp. 345-352, 2020, doi: 10.21776/ub.jam.2020.018.02.15.

[11] D. Al-Fraihat, M. Joy, R. Masa'deh, and J. Sinclair, "Evaluating E-learning systems success: An empirical study," Comput. Human Behav., vol. 102, no. August, pp. 6786, 2020, doi: 10.1016/j.chb.2019.08.004.

[12] R. Halonen, T. Acton, W. Golden, and K. Conboy, "DeLone \& McLean success model as a descriptive tool in evaluating a virtual learning environment," Int. Conf. Organ. Learn. Knowl. Capab. (OLKC 2009), no. 2008, p. 16, 2009, [Online]. Available: http://scholar.google.com/scholar?hl=en\&btnG=Search\&q=intitle:DeLone+\&+McLean + success + model + as + a + descriptive + tool + in + evaluating + a+virtual+learning+environme $\mathrm{nt} \# 0 \%$ Cnhttp://scholar.google.com/scholar?hl=en\&btnG=Search\&q=intitle:DeLone+ $\&+$ McLean + Success + model.

[13] M. Sarstedt, C. M. Ringle, and J. F. Hair, Handbook of Market Research, no. September. 2020. 